\title{
Crystal Structure of (2S,5R)-2-(tert-Butyl)-5-phenyl-5- (cyclopentyl-1-ol)-1,3-dioxolan-4-one
}

\author{
He LiU, ${ }^{\dagger}$ Xiang-Yu Han, Chun-He LiU, Bo-Hua Zhong, and Ke-Liang LiU \\ No.7 Department, Beijing Institute of Pharmacology and Toxicology, Beijing 100850, P. R. China
}

\begin{abstract}
(2S,5R)-2-(tert-Butyl)-5-phenyl-5-(cyclopentyl-1-ol)-1,3-dioxolan-4-one has been synthesized by (S)-mandelic acid as a chiral controller. The crystal structure reveals that the phenyl ring and the tert-butyl group are on the same side of the planar five-membered ring, and a quasi-one-dimensional zigzag chain structure was formed through $\mathrm{O} \cdots \mathrm{O}$ hydrogen bonds.
\end{abstract}

(Received June 1, 2004; Accepted July 12, 2004; Published on web September 22, 2004)

Tertiary hydroxy acids and esters are highly important components in the asymmetric synthesis of a variety of natural products and medicinal agents. ${ }^{1,2}$ Our recent drug candidate, $9 \alpha$-(3-azabicyclo[3,3,1]nonanyl)-2'-cyclopentyl-2'-hydroxy-2'phenylacetate, is a potent selective $\mathrm{M}_{1}$ antagonist. It is composed of a tertiary hydroxy acid as a key component, like the majority of muscarinic receptor antagonists. It exhibits classical antimuscarine side effects, such as dry mouth. The biology results suggest that the $(S)$-conformation compound displays an improved therapeutic profile compared to its racemic counterpart. In our efforts to production of enantiopure tertiary acid, (2S,5R)-2-(tert-butyl)-5-phenyl-5-(cyclopentyl-1ol)-1,3-dioxolan-4-one has been synthesized by $(S)$-mandelic acid as a chiral controller. It can be effectively transferred to tertiary hydroxy acid.

(2S,5R)-2-(tert-Butyl)-5-phenyl-1,3-dioxolan-4-one

synthesized by $(S)$-mandelic acid with pivaldehyde, as described in the literature. ${ }^{3}$ The title compound was prepared by a homogenized mixture of lithium bis(trimethylsilyl)amide and (2S,5R)-2-(tert-butyl)-5-phenyl-1,3-dioxolan-4-one in THF at $-78^{\circ} \mathrm{C}$. The reaction mixture was stirred for $0.5 \mathrm{~h}$ followed by the addition of cyclopentanone. After stirring for $1 \mathrm{~h}$, a saturated $\mathrm{NaHPO}_{4}$ solution was added. The reaction mixture was poured into the saturated $\mathrm{NH}_{4} \mathrm{Cl}$ solution. The aqueous layer was separated and extracted with ethyl acetate. After being concentrated in a vacuum, the crude product was obtained as a white solid. Crystals of the title complex suitable for X-ray analysis were recrystallized from heptane.

A colorless cubic crystal with dimensions of $0.36 \mathrm{~mm} \times 0.34$ $\mathrm{mm} \times 0.30 \mathrm{~mm}$ was mounted on a BRUKER SMART 1000 CCD diffractometer equipped with a graphite monochromator

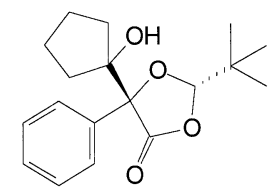

Fig. 1 Chemical structure of the present compound.

† To whom correspondence should be addressed.

E-mail: liuhe@nic.bmi.ac.cn for data collection. The determination of the unit-cell parameters and data collections were performed with Mo $K_{\alpha}$ radiation $(\lambda=0.71073 \AA)$. A total of 9530 reflections with 3388 independent ones with $R_{\text {int }}=0.0273$ with $I>2 \sigma(I)$ were collected in the range of $2.12<\theta<26.42^{\circ}$ by an $\omega / \theta$ scan mode at $298(2) \mathrm{K}$. All data were corrected by using the SADABS method. The structure was solved by direct methods with the SHELXS-97 program. ${ }^{4}$ The final refinement was performed by full-matrix least-squares methods with anisotropic thermal parameters for non-hydrogen atoms on $F^{2}$. The hydrogen atoms were added theoretically, riding on the concerned atoms and being refined with fixed thermal factors. The weighting scheme was $w=1 /\left[\sigma^{2}\left(F_{0}^{2}\right)+(0.0323 P)^{2}+0.1107 P\right]$, where $P=\left(F_{0}{ }^{2}+\right.$ $\left.2 F_{\mathrm{c}}^{2}\right) / 3$. The refinement converged to the final $R=0.0358$ and $w R=0.0711 . S=1.050$. Molecular graphics were drawn with the program package XP. Full crystallographic details have been deposited with the Cambridge Crystallographic Data Center, and were allocated the deposition number CCDC219010. Crystallographic data and experimental details for structural analyses are summarized in Table 1. Positional parameters and atomic coordinates are given in Table 2,

Table 1 Crystal and experimental data

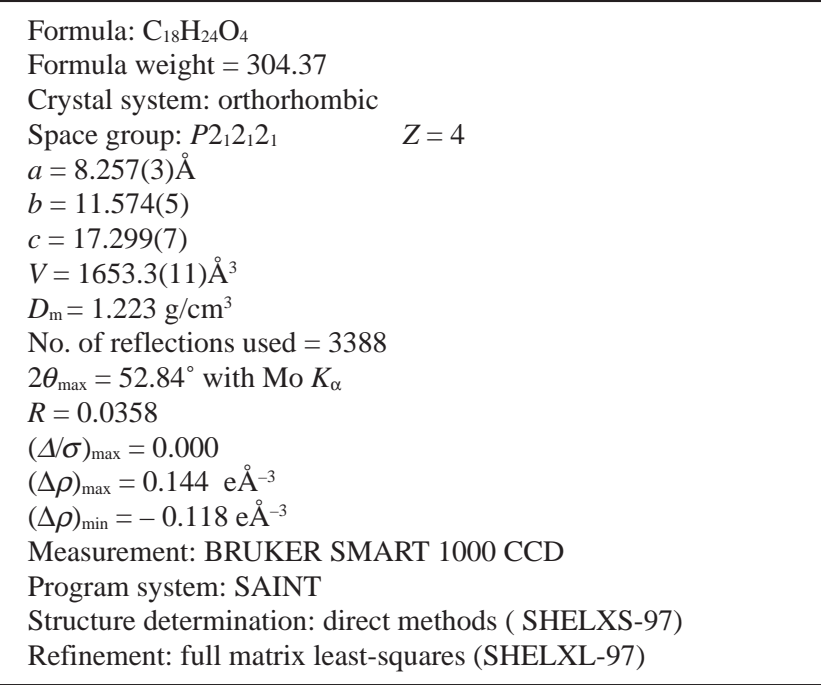


Table 2 Atomic coordinates $\left(\times 10^{4}\right)$ and equivalent isotropic displacement parameters $\left(10^{3} \times \AA^{2}\right)$

\begin{tabular}{lrrrr}
\hline Atom & $x$ & $y$ & $z$ & $U(\mathrm{eq})$ \\
\hline $\mathrm{O}(1)$ & $1530(1)$ & $4643(1)$ & $1994(1)$ & $44(1)$ \\
$\mathrm{O}(2)$ & $2437(1)$ & $6079(1)$ & $2777(1)$ & $51(1)$ \\
$\mathrm{O}(3)$ & $4343(2)$ & $6881(1)$ & $2049(1)$ & $58(1)$ \\
$\mathrm{O}(4)$ & $4731(2)$ & $4099(1)$ & $2299(1)$ & $60(1)$ \\
$\mathrm{C}(1)$ & $1482(2)$ & $5039(1)$ & $2765(1)$ & $44(1)$ \\
$\mathrm{C}(2)$ & $3336(2)$ & $6145(1)$ & $2140(1)$ & $42(1)$ \\
$\mathrm{C}(3)$ & $2846(2)$ & $5173(1)$ & $1589(1)$ & $37(1)$ \\
$\mathrm{C}(4)$ & $4254(2)$ & $4300(1)$ & $1517(1)$ & $40(1)$ \\
$\mathrm{C}(5)$ & $3769(2)$ & $3177(2)$ & $1111(1)$ & $55(1)$ \\
$\mathrm{C}(6)$ & $5335(3)$ & $2656(2)$ & $806(1)$ & $66(1)$ \\
$\mathrm{C}(7)$ & $6632(2)$ & $3567(2)$ & $906(1)$ & $65(1)$ \\
$\mathrm{C}(8)$ & $5721(2)$ & $4683(2)$ & $1054(1)$ & $50(1)$ \\
$\mathrm{C}(9)$ & $2213(2)$ & $5625(1)$ & $820(1)$ & $42(1)$ \\
$\mathrm{C}(10)$ & $866(2)$ & $5123(2)$ & $486(1)$ & $60(1)$ \\
$\mathrm{C}(11)$ & $335(3)$ & $5484(2)$ & $-229(1)$ & $84(1)$ \\
$\mathrm{C}(12)$ & $1088(4)$ & $6359(3)$ & $-608(1)$ & $91(1)$ \\
$\mathrm{C}(13)$ & $2404(4)$ & $6888(2)$ & $-282(1)$ & $82(1)$ \\
$\mathrm{C}(14)$ & $2972(3)$ & $6525(2)$ & $432(1)$ & $59(1)$ \\
$\mathrm{C}(15)$ & $-235(2)$ & $5274(2)$ & $3034(1)$ & $50(1)$ \\
$\mathrm{C}(16)$ & $-1119(2)$ & $4119(2)$ & $3059(1)$ & $77(1)$ \\
$\mathrm{C}(17)$ & $-135(3)$ & $5790(2)$ & $3848(1)$ & $76(1)$ \\
$\mathrm{C}(18)$ & $-1090(2)$ & $6109(2)$ & $2489(1)$ & $71(1)$ \\
\hline
\end{tabular}

$U(\mathrm{eq})$ is defined as one third of the trace of the orthogonalized $U \mathrm{ij}$ tensor.

Table 3 Bond distances $(\AA)$ and bond angles $\left({ }^{\circ}\right)$

\begin{tabular}{|c|c|c|c|}
\hline $\mathrm{O}(1)-\mathrm{C}(1)$ & $1.4116(18)$ & $C(7)-C(8)$ & $1.517(3)$ \\
\hline $\mathrm{O}(1)-\mathrm{C}(3)$ & $1.4314(17)$ & $\mathrm{C}(9)-\mathrm{C}(10)$ & $1.382(2)$ \\
\hline $\mathrm{O}(2)-\mathrm{C}(2)$ & $1.3301(18)$ & $\mathrm{C}(9)-\mathrm{C}(14)$ & $1.388(2)$ \\
\hline $\mathrm{O}(2)-\mathrm{C}(1)$ & $1.4397(19)$ & $\mathrm{C}(10)-\mathrm{C}(11)$ & $1.376(3)$ \\
\hline $\mathrm{O}(3)-\mathrm{C}(2)$ & $1.2004(18)$ & $\mathrm{C}(11)-\mathrm{C}(12)$ & $1.358(4)$ \\
\hline $\mathrm{O}(4)-\mathrm{C}(4)$ & $1.4289(18)$ & $\mathrm{C}(12)-\mathrm{C}(13)$ & $1.369(4)$ \\
\hline$C(1)-C(15)$ & $1.516(2)$ & $C(13)-C(14)$ & $1.386(3)$ \\
\hline $\mathrm{C}(2)-\mathrm{C}(3)$ & $1.530(2)$ & $C(15)-C(16)$ & $1.523(3)$ \\
\hline $\mathrm{C}(3)-\mathrm{C}(9)$ & $1.523(2)$ & $\mathrm{C}(15)-\mathrm{C}(18)$ & $1.524(3)$ \\
\hline $\mathrm{C}(3)-\mathrm{C}(4)$ & $1.545(2)$ & $C(15)-C(17)$ & $1.532(2)$ \\
\hline $\mathrm{C}(4)-\mathrm{C}(8)$ & $1.518(2)$ & $\mathrm{C}(5)-\mathrm{C}(6)$ & $1.521(3)$ \\
\hline $\mathrm{C}(4)-\mathrm{C}(5)$ & $1.531(2)$ & $C(6)-C(7)$ & $1.513(3)$ \\
\hline $\mathrm{C}(1)-\mathrm{O}(1)-\mathrm{C}(3)$ & $110.17(11)$ & $C(11)-C(10)-C(9)$ & $120.3(2)$ \\
\hline $\mathrm{C}(2)-\mathrm{O}(2)-\mathrm{C}(1)$ & $109.99(11)$ & $\mathrm{C}(12)-\mathrm{C}(11)-\mathrm{C}(10)$ & $120.9(2)$ \\
\hline $\mathrm{O}(1)-\mathrm{C}(1)-\mathrm{O}(2)$ & $105.65(11)$ & $\mathrm{C}(11)-\mathrm{C}(12)-\mathrm{C}(13)$ & $119.9(2)$ \\
\hline $\mathrm{O}(1)-\mathrm{C}(1)-\mathrm{C}(15)$ & $112.00(12)$ & $\mathrm{C}(12)-\mathrm{C}(13)-\mathrm{C}(14)$ & $120.0(2)$ \\
\hline $\mathrm{O}(2)-\mathrm{C}(1)-\mathrm{C}(15)$ & $111.02(13)$ & $\mathrm{C}(13)-\mathrm{C}(14)-\mathrm{C}(9)$ & $120.3(2)$ \\
\hline $\mathrm{O}(3)-\mathrm{C}(2)-\mathrm{O}(2)$ & $122.39(14)$ & $\mathrm{C}(1)-\mathrm{C}(15)-\mathrm{C}(16)$ & $107.43(14)$ \\
\hline $\mathrm{O}(3)-\mathrm{C}(2)-\mathrm{C}(3)$ & $128.53(14)$ & $C(1)-C(15)-C(18)$ & $110.90(15)$ \\
\hline $\mathrm{O}(2)-\mathrm{C}(2)-\mathrm{C}(3)$ & $109.08(13)$ & $C(16)-C(15)-C(18)$ & $110.62(16)$ \\
\hline $\mathrm{O}(1)-\mathrm{C}(3)-\mathrm{C}(9)$ & $108.34(12)$ & $\mathrm{C}(1)-\mathrm{C}(15)-\mathrm{C}(17)$ & $107.56(14)$ \\
\hline $\mathrm{O}(1)-\mathrm{C}(3)-\mathrm{C}(2)$ & $102.17(12)$ & $C(16)-C(15)-C(17)$ & $110.05(16)$ \\
\hline $\mathrm{C}(9)-\mathrm{C}(3)-\mathrm{C}(2)$ & $112.48(12)$ & $C(18)-C(15)-C(17)$ & $110.21(15)$ \\
\hline $\mathrm{O}(1)-\mathrm{C}(3)-\mathrm{C}(4)$ & $109.32(11)$ & $C(8)-C(4)-C(3)$ & $116.84(12)$ \\
\hline $\mathrm{C}(9)-\mathrm{C}(3)-\mathrm{C}(4)$ & $114.36(11)$ & $C(5)-C(4)-C(3)$ & $113.27(13)$ \\
\hline $\mathrm{C}(2)-\mathrm{C}(3)-\mathrm{C}(4)$ & $109.43(12)$ & $\mathrm{C}(6)-\mathrm{C}(5)-\mathrm{C}(4)$ & $105.81(15)$ \\
\hline $\mathrm{O}(4)-\mathrm{C}(4)-\mathrm{C}(8)$ & $109.11(13)$ & $\mathrm{C}(7)-\mathrm{C}(6)-\mathrm{C}(5)$ & $106.65(15)$ \\
\hline $\mathrm{O}(4)-\mathrm{C}(4)-\mathrm{C}(5)$ & $111.66(13)$ & $C(6)-C(7)-C(8)$ & $105.16(14)$ \\
\hline $\mathrm{C}(8)-\mathrm{C}(4)-\mathrm{C}(5)$ & $102.43(13)$ & $\mathrm{C}(7)-\mathrm{C}(8)-\mathrm{C}(4)$ & $103.59(14)$ \\
\hline $\mathrm{O}(4)-\mathrm{C}(4)-\mathrm{C}(3)$ & $103.71(11)$ & $C(10)-C(9)-C(14)$ & $118.50(16)$ \\
\hline$C(10)-C(9)-C(3)$ & $119.79(15)$ & $C(14)-C(9)-C(3)$ & $121.69(15)$ \\
\hline
\end{tabular}

whereas the selected bond distances and angles are listed in Table 3, respectively.

The ORTEP structure of the title compound with atomic labeling is shown in Fig. 2(a). The phenyl ring and the tertbutyl group are on the same side of the five-membered ring, which is unlike the structures of malic acid or lactic acid derivatives, such as 5-methyl-2-(trichloromehtyl)-1,3-dioxolan-
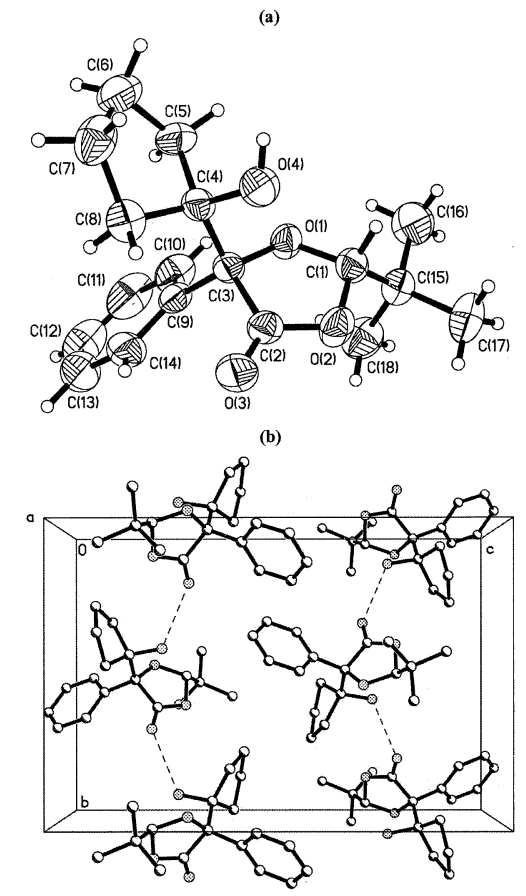

Fig. 2 (a) ORTEP structure of the title compound with atom labeling; (b) Packing diagram for the title compound showing the hydrogen bonding.

4-one. ${ }^{5,6}$ The five-membered ring is essentially planar with an average deviation of $0.0621 \AA$ form the least-squares plane. The carbonyl group lies in this plane $\left(\mathrm{C} 1-\mathrm{O} 2-\mathrm{C} 2-\mathrm{O} 3=173.1^{\circ}\right)$. The cyclopentyl-1-ol group lies on the opposite side of the tertbutyl group. As shown in Fig. 2(b), a quasi-one-dimensional zigzag chain structure was formed through $\mathrm{O} \cdots \mathrm{H}-\mathrm{O}$ hydrogen bonds in which the carbonyl oxygen atom of the carbonyl group links the hydroxyl group in the adjacent molecule. The $\mathrm{O} \cdots \mathrm{O}$ separation is $2.906 \AA$ with the $\mathrm{H}$... O separation being $2.132 \AA$, and the $\mathrm{O} \cdots \mathrm{H}-\mathrm{O}$ angle is $157.56^{\circ}$.

\section{Acknowledgements}

This work was financially supported by the National Natural Science Foundation of China (No. 30271492).

\section{References}

1. G. Barbaro, A. Battaglia, and A. Guerrini, J. Org. Chem., 1999, 64, 4643.

2. S. L. Schreiber, and R. J. Valentekovich, J. Am. Chem. Soc., 1995, 117, 9069.

3. P. T. Grover, N. N. Bhongle, S. A. Wald, and C. H. Senanayake, J. Org. Chem., 2000, 65, 6283.

4. Sheldrick, SHELXS-97, Program for X-ray Crystal Structure Solution; Göttingen University: Germany, 1997; Sheldrick, G. M. SHELXL-97, Program for X-ray Crystal Structure Refinement; Göttingen University: Germany, 1997.

5. L. L. Koh, H. H. Huang, L. H. L. Chia, and E. P. Liang, J. Mol. Struct., 1995, 351, 147.

6. W. Z. Pang, H. H. Huang, and L. L. Koh, J. Mol. Struct., 1997, 415, 17. 